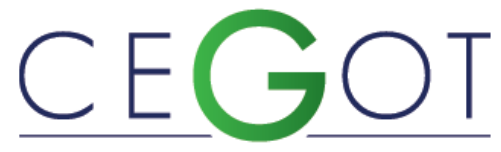

Centro de Estudos de Geografia e Ordenamento do Território
Geografia e Ordenamento do Território, Revista Eletrónica Centro de Estudos de Geografia e Ordenamento do Território http://cegot.org ISSN: 2182-1267
AYER, JOAQUIM ERNESTO BERNARDES

UNICAMP - Universidade Estadual de Campinas - Instituto de Geociências

13083-855, Campinas, Brasil. Rua Carlos Gomes 250, Cidade Universitária.

joaquimeba@gmail.com

\section{LÄMMLE, LUCA}

UNICAMP - Universidade Estadual de Campinas - Instituto de

Geociências

13083-855, Campinas, Brasil. Rua Carlos Gomes 250, Cidade Universitária.

lucalammle@ige.unicamp.br

\section{GaRofalo, DANiLo Francisco Trovo}

Embrapa Meio Ambiente

13918-110, Jaguariúna, Brasil. Rodovia SP-340, Km 127.

danilo.trovo.garofalo@gmail.com

Mincato, RonALDo LUIZ

UNIFAL - Universidade Federal de Alfenas - Instituto de Ciências da Natureza

37130-001, Alfenas, Brasil. Rua Gabriel Monteiro da Silva 700, Centro.

ronaldo.mincato@unifal-mg.edu.br

\section{SERVIDONI, LUCAS EMANUEL}

UNIFAL - Universidade Federal de Alfenas - Instituto de Ciências da Natureza

37130-000, Alfenas, Brasil.

lucas.servidoni@sou.unifal-mg.edu.br

\section{Pereira, Sueli Yoshinaga}

UNICAMP - Universidade Estadual de Campinas - Instituto de

Geociências

13083-855, Campinas, Brasil. Rua Carlos Gomes 250, Cidade Universitária.

sueliyos@ige.unicamp.br

\title{
Dinâmica espaço-temporal do uso e ocupação da terra no Município de Ribeirão Preto, São
}

\section{Paulo, Brasil.}

Space-temporal dynamics of land use and occupation in the Municipality of Ribeirão Preto, São Paulo,

Brazil.

Referência: Ayer, Joaquim Ernesto Bernardes; Lämmle, Luca; Garofalo, Danilo Francisco Trovo; Mincato, Ronaldo Luiz; Servidoni, Lucas Emanuel; Pereira, Sueli Yoshinaga (2021). Dinâmica espaço-temporal do uso e ocupação da terra no Município de Ribeirão Preto, São Paulo, Brasil. Revista de Geografia e Ordenamento do Território (GOT), n.o 21 (Junho). Centro de Estudos de Geografia e Ordenamento do Território, p. 88-120, dx.doi.org/ 10.17127/got/2021.21.004 


\section{RESUMO}

O ordenamento territorial na Região Sudeste do Brasil foi marcado por ciclos econômicos marcantes de uso e ocupação da terra. Para avaliar tal dinâmica foram realizados levantamentos de dados históricos e naturais do Município de Ribeirão Preto-SP. Neste contexto, foi adotado o método de análise espaço-temporal, baseado no mapeamento do uso e ocupação da terra, a partir da reconstituição do mapa de do uso de 1910, junto aos mapeamentos de imagens de satélite e fotografias aéreas pelo método da classificação orientada a objeto de 1973, 1985, 1995, 2005, 2015, 2019. O objetivo foi quantificar os usos, traçar tendências, avaliar a efetividade das políticas públicas e destacar potencialidades e riscos ambientais. Os mapas revelam o crescimento e expansão das fronteiras agropecuárias, que indica uma mudança da base econômica da região, que passou de grande produtor de café para um polo de produção de cana-de-açúcar e agroindustrial. Tais mudanças refletem a queda de preço do café e os programas federais de incentivo à produção de açúcar e etanol. Assim, a estrutura fundiária não sofreu grandes alterações e continua com o predomínio das grandes propriedades, mas agora geridas por holdings e sociedades anônimas. Já, a urbanização ocorreu de forma acelarada e foi impulsionada pela revolução verde, principalmente a partir de 1960, resultando no forte exôdo rural na região. Este processo, resultou em uma série de impactos socioambientais, relacionados às ocupações irregulares de áreas para moradias e aumento da violência urbana e rural, além do aumento da demanda por recursos naturais, como, por exemplo, o aumento da demanda de água e por consequência das águas do Sistema Aquífero Guarani, que resultou no rebaixamento do lençol freático e causou restrições ao seu uso. Além disto, a vegetação nativa da região foi quase totalmente desmatada e os solos apresentam, localmente, sinais de erosão acelerada, que tende a impactar de forma deletéria os recursos hídricos superfíciais, que já sofrem com os despejos de efluentes municipais e industriais. Neste contexto, a região de Ribeirão Preto é um polo econômico agropecuário mundial, que depende de seu potencial natural. Portanto, o planejamento sustentável do uso e ocupação territorial deve ter como prioridade proteger e preservar estes recursos naturais, visto a dependência histórica do município dele.

Palavras-chave: Direito Ambiental; Planejamento Territorial; Análise Geoespacial; Classificação Orientada a Objeto.

\section{ABSTRACT}

The territorial planning in the Southeast Region of Brazil was marked by marked economic cycles of land use and occupation. To assess this dynamic, surveys of historical and natural data from Ribeirão Preto - SP. In this context, the method of space-temporal analysis was adopted, based on the mapping of land use and occupation, from the reconstitution of the map of the use of 1910, together with the mapping of satellite images and aerial photographs by the method of oriented classification the object of 1973, 1985, 1995, 2005, 2015,2019 . The objective was to quantify the uses, trace trends, evaluate the effectiveness of public policies and highlight potential and environmental risks. The maps reveal the growth and expansion of agricultural frontiers, which indicates a change in the region's economic base, which has gone from being a major coffee producer to a sugarcane and agribusiness production hub. Such changes reflect the drop in the price of coffee and the federal programs to encourage the production of sugar and ethanol. Thus, the land ownership structure has not undergone major changes and continues to be dominated by 
large properties, but now managed by holding companies and anonymous society. Urbanization took place at an accelerated rate and was driven by the green revolution, mainly from 1960, resulting in the strong rural exodus in the region. This process resulted in a series of socio-environmental impacts, related to irregular occupations of areas for housing and increased urban and rural violence, in addition to the increased demand for natural resources, such as, for example, the increased demand for water and consequently of the waters of the Guarani Aquifer System, which resulted in the lowering of the water table and caused restrictions on its use. In addition, the region's native vegetation has been almost completely deforested and the soils show signs of accelerated erosion locally, which tends to have a deleterious impact on surface water resources, which are already suffering from municipal and industrial effluent discharge. In this context, the Ribeirão Preto region is a global agricultural economic hub, which depends on its natural potential. Therefore, the sustainable planning of territorial use and occupation should have as a priority to protect and preserve these natural resources, given the historical dependence of the municipality on it.

Keywords: Environmental Law; Territorial Planning; Geospatial Analysis; Object Oriented Classification.

\section{Introdução}

As alterações de uso e cobertura do solo são cada vez mais frequentes e intensas e podem, de acordo com as técnicas de manejo adotadas, representar avanços ou gerar impactos deletérios aos recursos naturais e ao desenvolvimento socioeconômico e ambiental. De tal modo, o uso do território representa a classe de cobertura e sua função socioeconômica, que muitas vezes é regulamentado por leis (Martínez, 2014). Já o manejo do solo, representa as práticas aplicadas para o aumento e manutenção da sua capacidade produtiva. Inclui práticas e operações de cultivo, de correção, de fertilização, de mecanização e de irrigação. Os manejos podem ser o conservacionista, que integra preservação ambiental e produção, e o convencional, que busca retorno econômico de curto prazo ao menor custo. Este último pode causar, a médio e longo prazo, a dilapidação do capital natural (Embrapa, 2018). Portanto, o monitoramento periódico da evolução espaço-temporal do uso, ocupação e manejo do solo permite tornar esta dinâmica sustentável e contribui para promover a mitigação dos impactos ambientais e a conservação da capacidade produtiva dos sistemas agrícolas.

A dinâmica espaço-temporal do uso e cobertura do solo possibilita acompanhar e propor mecanismos de controle, para avaliar as alterações, suas causas e consequências, ao longo do tempo. Auxilia ainda a elaboração de políticas públicas eficientes e viabiliza a adoção e 
avaliação de estratégias de curto, médio e longo prazo para regulamentar a ocupação territorial.

Para atingir este objetivo, métodos de classificação digital de imagens orientada a objeto e geoestatísticos permitem segmentar as imagens em distintos alvos homogêneos com propriedades comuns, como reflectância, textura, padrão e forma, entre outros atributos da imagem. Os alvos correspondem aos diferentes usos e permitem quantificar e monitorar a ocupação territorial (Ponzoni et al., 2012).

Neste cenário, o histórico de deslocamentos e de mudanças de ocupação territorial podem ser compreendidos a partir de dois fatores. O primeiro é a dinâmica natural ou potencialidades e limitações naturais de ocupação do território, como disponibilidade de água, relevos íngremes ou planos, solos pedregosos, ocorrência de desastres naturais e climas hostis ou favoráveis. O segundo envolve as particularidades culturais e tecnológicas da população, que permitem superar as limitações naturais e se fixar num território, em sociedades mais desenvolvidas. Este processo é regulado por leis que dependem em parte da conjuntura tecnológica e cultural da população. Assim, foi traçado o panorama histórico da ocupação territorial a partir da configuração espacial, no qual o meio físico oferece potencialidades e fragilidades para ocupação, que levam a diferentes estratégias e formas de ocupação territorial, pautando e comparando, quando possível, o processo de desenvolvimento da legislação ambiental com os mapas de uso e ocupação do solo.

Para tanto, o Município de Ribeirão Preto (Figura 1) foi escolhido para o estudo, pois permite analisar de forma integrada o desenvolvimento e ocupação desse território no NW do Estado de São Paulo, de modo a avaliar, como o uso e ocupação do território repercutiram nas políticas de planejamento territorial e ambiental. A área apresenta as características de praticamente todos os ciclos econômicos que marcaram a ocupação da região e contribui, como área piloto, para o entendimento da dinâmica regional dos usos e das legislações sobre o meio natural e social.

Ribeirão Preto é caracterizada pela abundância recursos pedológicos e hídricos, além da localização sobre a área de recarga do Sistema Aquífero Guarani - SAG. Assim, foi avaliado como os impactos antrópicos, os avanços tecnológicos e as políticas ambientais repercutem na dinâmica de ocupação territorial. 


\section{Materiais e Métodos}

\section{1 Área de Estudo}

O Município de Ribeirão Preto (Figura 1) está localizado no Noroeste do Estado de São Paulo com 65.177 há, com estimativa de 694.534 habitantes (IBGE, 2019). Possui uma das mais dinâmicas economias do Brasil, com PIB de cerca de 7,5 bilhões de dólares. Apresenta elevadas taxas de crescimento demográfico e Índice de Desenvolvimento Humano (IDH) de 0,800 , reputado elevado para o país. É, ainda, um dos principais polos sucroalcooleiros da América Latina (PMRP, 2015).

O clima de Ribeirão Preto é classificado como tropical mesotérmico, subtipo - Cwa, segundo classificação Köppen, com precipitação entre 1.300 a $1.600 \mathrm{~mm}$ ano-1, com invernos secos e frios e verões chuvosos e quentes (Alvares et al., 2014). A área faz parte da Bacia Sedimentar do Paraná, onde afloram rochas basálticas de idade Cretácica da Formação Serra Geral e sedimentares de idade Juro-Cretácica das Formações Botucatu e Pirambóia, cujo conjunto forma o Grupo São Bento (Sinelli, 1973). A Formação Botucatu é composta por arenitos com estratificações cruzadas, característicos de ambientes desérticos, com granulação fina a média bem selecionada, que possui ainda características homogêneas de permeabilidade e de facilidade de circulação e armazenamento de água. 


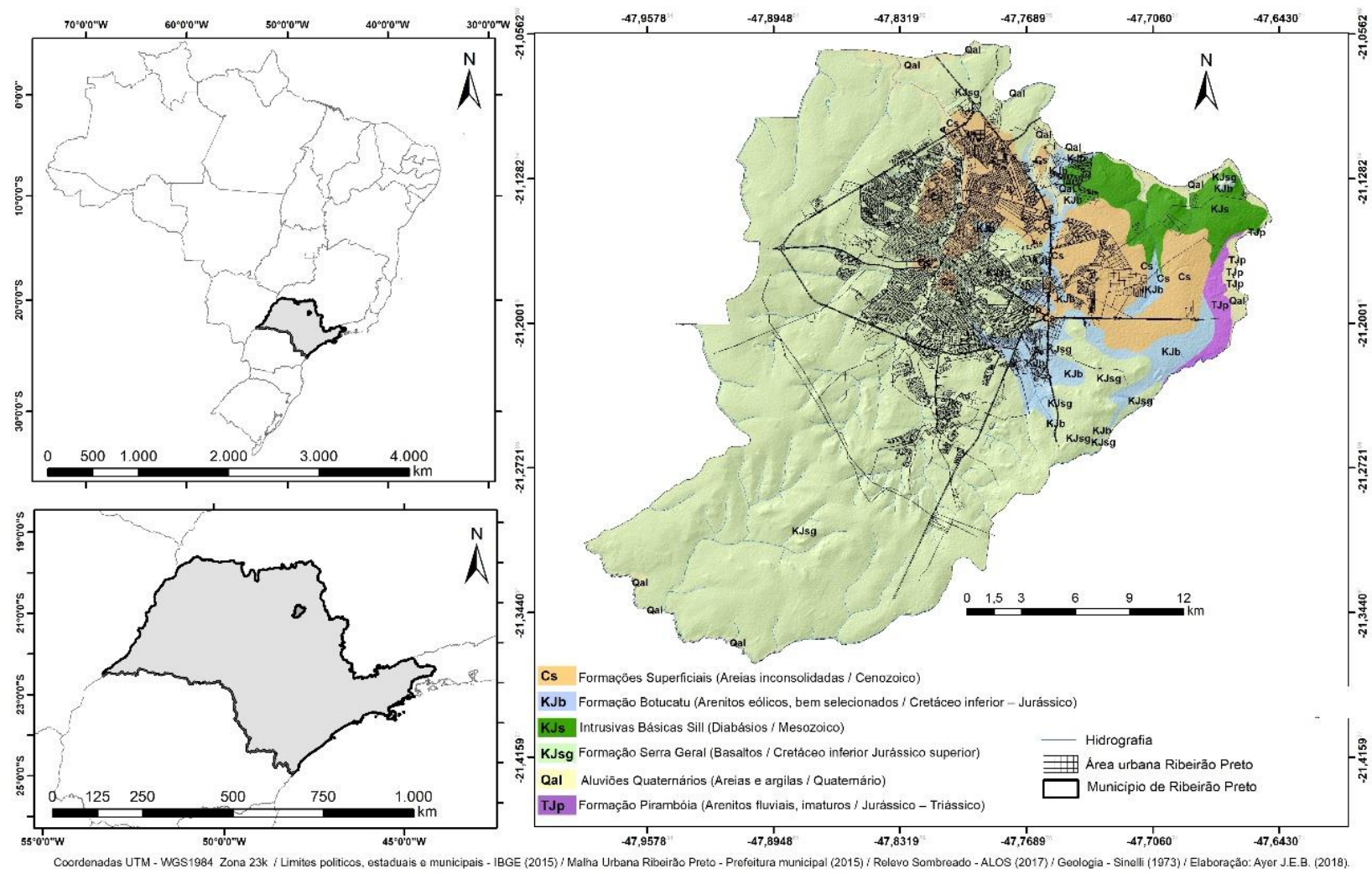

Figura 1 - Mapa de localização e geológico do Município de Ribeirão Preto - SP.

Sobre estas rochas, principalmente sobre as basálticas, ocorrem ainda espessas camadas de Latossolos Vermelhos, denominados de Terra Roxa. O termo originário dos imigrantes italianos que nomearam tais solos de Terra Rossa, literalmente terra vermelha, que foi aportuguesada pelos nativos para Terra Roxa, que junto aos recursos hídricos são os responsáveis pela ocupação e pelo dinamismo econômico da região (PMRP, 2015). Estas rochas formam o chamado Sistema Aquífero Guarani (SAG), que representa um dos principais recursos naturais da região e um dos maiores do mundo.

\subsection{Análise Espacial e Compilação dos Dados}

Para suporte teórico e discussão da evolução dos processos de uso e ocupação do noroeste paulista foi realizado estudos de revisão de bibliografia, entrevistas informais com moradores e mapeamentos. Assim, foram avaliadas as características ambientais e a ocupação da região e seus reflexos na legislação sobre o ordenamento territorial. Assim, foram obtidos e realizados os mapeamentos do uso e ocupação do solo, de geologia na 
escala 1:250.000 (Sinelli, 1973); vegetação pretérita (IBGE 2012), limites municipais brasileiros (IBGE, 2013) e da hidrografia. Além destes, foram compiladas séries históricas de dados estatísticos e geográficos de autarquias públicas do município.

A dinâmica de uso e ocupação do território foi avaliada a partir de reconstituições espaçotemporais com dados históricos e biogeográficos e mapeamentos digitais com dados de sensores orbitais. Primeiro, foi gerada a reconstituição do uso e ocupação do município no entorno de 1900, a partir dos mapas citados, além da vegetação de 1962, deste estudo e da área urbana (PMRP, 2015) e da carta topográfica Folha Orlândia de 1925 da Comissão Geográfica e Geológica do Estado de São Paulo - CGGESP. Para delimitação das classes de uso foi considerado que a classe mata nativa deriva da soma das classes matas (IBGE, 2012) mais as áreas presentes no mapa de uso de 1962, assumindo que as matas de 1962 já existiam em 1900. Para a classe Cerrado (Savana) foi adotada a mesma da vegetação pretérita (IBGE, 2012), pois em 1962 ainda existiam grandes remanescentes deste bioma. A área urbana foi obtida dos registros oficiais. Para o uso agropecuário foi criada a classe agricultura com predomínio de café, pela dificuldade de separar os usos agropecuários a partir dos dados derivados dos mapas de CGGESP (1910) e Sociedade Nacional de Agricultura - SNA de 1908. Diante disso, foi assumido que a produção agrícola estava distribuída principalmente sobre as áreas com rochas de origem ígnea (Figura 1) onde se localizam as chamadas terras roxas de alta fertilidade, visto que na época não era possível corrigir a fertilidade dos solos e nem cultivar café em várzeas.

Os mapeamentos com imagens/bandas multiespectrais foi realizado a partir de imagens obtidas no repositório Earth Explorer, dos satélites Landsat: bandas 4, 5, 6 e 7 do Landsat-3 MSS (MultiSpectral Scanner), de 31/07/1973; bandas 1, 2, 3, 4, 5 e 7 do Landsat-5 TM (Thematic Mapper), de 20/04/1985, 16/04/1995 e 11/04/2005 e bandas 1, 2, 3, 4, 5, 6 e 7 do Landsat-8 OLI (Operational Land Imager), de 09/05/2015 e 18/04/2019. As imagens foram obtidas entre maio e agosto por caracterizar o período seco e de reduzido o efeito atmosférico. Para 1962, foi utilizada a cobertura aerofotogramétrica do Estado de São Paulo.

A resolução espacial, radiométrica e temporal das imagens variaram devido à evolução da tecnologia dos satélites Landsat e de seus sensores (USGS, 2016). Assim, imagens do sensor MSS possuem resolução espacial de $80 \mathrm{~m}$, que pode causar erros maiores de classificação, 
em relação a imagens dos sensores TM e OLI, com resolução de $30 \mathrm{~m}$. As imagens foram processadas no software ENVI 5.3 e o layout dos produtos no software ArcGis 10.6. Foram realizadas etapas de pré-processamento e correção geométrica na imagem de 1962 . As demais imagens foram obtidas já georreferenciadas ao sistema WGS 1984 (World Geodetic System). As imagens Landsat 5 e 8 foram obtidas com correção atmosférica, e a imagem do Landsat 3 foi corrigida com o módulo "fast line-of-sight atmospheric analysis of spectral hypercubes" (Flaash) (Felde et al., 2003).

Na sequência, as bandas multiespectrais referentes a uma data foram empilhadas. Do arquivo, em composição falsa-cor (R5G4B6), com contraste linear de $2 \%$, a partir de inspeções no Google Earth Pro, verificações em campo, entrevistas informais com moradores e dados do censo agropecuário (IBGE, 2006) de diversos anos. Assim, foram definidas 8 classes de uso e cobertura do solo: área urbana, vias e sedes rurais; mineração; corpos hídricos; culturas temporárias; culturas permanentes; pastagem; mata nativa e campos higrófilos de várzea.

No mapeamento do uso e cobertura do solo foi feita a classificação orientada a objetos, baseada na informação espectral de cada pixel e a espacial que corresponde à características dos alvos, como forma e textura (Ponzoni et al., 2012). Primeiro, as imagens são segmentadas no "Envi feature extraction" do ENVI 5.3, que as particiona em porções similares, com base em atributos espectrais, de forma e de textura. Os pixels são, assim, agrupados pelo nível de escala, de 1 a 100, que define a densidade da segmentação, e para unir segmentos menores em áreas maiores foi usado o nível de agregação, que também varia de 1 a 100 e une segmentos vizinhos pela combinação espectral e espacial.

Com base nos resultados preliminares foram definidos os valores 35 para o limiar do nível de escala e 87 para o limiar do nível de agregação das imagens Landsat 5 e 8, enquanto para as imagens de 1973 (Landsat 3), 1962 (aerofotografia) foram utilizados, respectivamente, os limiares, 50 e 50 e 80 e 60 e obtidos os shapefile de segmentos. Do arquivo sobreposto à composição R5G4B6 foram extraídas, visualmente, cerca de 600 segmentos para cada classe de uso em cada ano, que foram utilizados no treinamento do classificador automático. Os segmentos foram selecionados por análise visual. A partir da segmentação foi realizada a classificação digital de imagem, com o algoritmo estatístico, não paramétrico, Support 
Vector Machines (SVM) (Huang et al., 2002), disponível no ENVI FX, que classifica os segmentos a partir dos atributos espectrais, de forma e de textura de cada objeto.

A partir dos dados de uso e cobertura do solo foram gerados gráficos da evolução temporal do uso e ocupação das terras. Tais mapas foram comparados para avaliar os padrões de uso, a partir de critérios dialéticos históricos. Todavia, para compreensão da dinâmica de uso e ocupação do território, foram incorporados a questão legal e os fatores naturais.

\section{Resultados e Discussão}

\subsection{Evolução espaco-temporal do uso e cobertura do Município de Ribeirão Preto}

O Município de Ribeirão Preto possuía como vegetação pretérita o Cerrado (Savana) que cobria 16.655 ha (Figura 2A), nas áreas mais baixas e com litologias sedimentares ao norte (Figura 1). As áreas mais altas, ao centro do município, com litologias ígneas, eram cobertas por floresta estacional semidecidual de montana com 1.684 ha, enquanto nas áreas de várzea, tinham como cobertura floresta estacional semidecidual aluvial com 3.354 ha (Figura 1). Todavia, a maior parte do território era coberta pela transição entre Cerrado (Savana) e florestas estacionais com 43.448 ha. Esta vegetação, num primeiro momento, sofreu a ação dos povos indígenas, das etnias Guarani e Terena, que geralmente se restringiam a pequenas aldeias com roçados familiares próximos às aldeias ou comunidades, onde eram produzidos mandioca, amendoim, milho e frutas sem causar prejuízos à vegetação nativa.

Os indígenas foram, paulatinamente, aculturados e exterminados pelos sertanistas, que, desde o Século XVI, partiram em expedições em busca de escravos e minérios (Ribeiro, 2006). Porém, no final do Século XVIII, com a decadência do sistema aurífero das Minas Gerais e a diversificação econômica, muitas pessoas passaram a buscar novas fronteiras, normalmente em áreas devolutas, que resultou na migração de posseiros para a região de Ribeirão Preto, que lá se fixaram e tinham como principal atividade o cultivo do café (Marcondes et al., 2015) (Figura 2B). A região atraia pela abundância de água, relevo plano e solos férteis, ideais para agricultura. Porém, com a chegada da corte portuguesa ao Rio de Janeiro, no início do Século XIX, a migração para a área foi intensificada. Na ocasião, 
posseiros brasileiros, imigrantes principalmente portugueses e africanos escravizados passaram a ocupar a região.

A área do município começou a ser povoada por volta de 1810 , por migrantes oriundos principalmente das Minas Gerais (Marcondes et al., 2015). Todavia, apenas a partir da doação de terras por fazendeiros locais, para a construção da capela de São Sebastião, é que teve início a formação do núcleo urbano que viria a constituir o Município de Ribeirão Preto (Figura 2B). A formação oficial de Ribeirão Preto é 1856 (Emboaba, 1955). Porém, para alguns autores como Barros (2005), que afirma que formação do município foi em 1853. Cabe destacar que a Vila de São Sebastião do Rio Preto da qual se originou o município de Ribeirão Preto, abarcava também os territórios dos atuais Municípios de Sertãozinho e Cravinhos, emancipados a municípios no ano 1896.

Naquela época, as terras eram divididas em sesmarias e doadas aos colonizadores. Todavia, muitos posseiros migraram para a região e iniciaram a construção dos primeiros arraiás e vilas de maneira mais efetiva que os sesmeiros, inserindo-as no sistema de administração colonial. Foi assim, na segunda metade do Século XIX que iniciou o processo de uso e ocupação que originaria o Município de Ribeirão Preto. No período, a população era formada, sobretudo por imigrantes portugueses, brasileiros e escravos, que irão constituir a figura folclórica do caipira paulista. Em relação à escravidão, em 1874, o município chegou a possuir 857 escravos, correspondendo a 15,5\% da população de 5.552 habitantes, atingindo 1.379 indivíduos em 1886 (Emboaba, 1955; Marcondes et al., 2015). Com a abolição da escravatura em 1888, estas populações passaram a sofrer com o descaso do poder público e da sociedade e ficaram à mercê de condições precárias de vida e sem o amparo de políticas públicas (Ribeiro, 2006). Ao contrário, porém os proprietários de escravos foram indenizados pelo governo pelas perdas resultantes da libertação dos escravos, permitindo aos mesmos ampliarem seu poder econômico, porém não foi dada a indenização prevista pelo governo imperial para os escravos libertos (Araújo, 2017).

Na primeira fase de desenvolvimento do município, no uso e ocupação havia uma escassa ocupação urbana e domínio de população rural, que produzia de milho, café, feijão, fumo, algodão, pecuária e, principalmente, cana-de-açúcar. Depois, muitos migrantes chegaram à região, vindos principalmente do Vale do Paraíba, local que enfrentava oscilações e crises no mercado de café, o que gerava excedentes de mão de obra que migraram para a região. 
Estes migrantes trouxeram a cultura do café que se expandiu rapidamente, com a linha férrea Mogiana, em 1883, que foi financiada por fazendeiros locais que buscavam ampliar a competitividade de suas fazendas e resultou em grande área ocupada por cafezais (Figura 2B). Isto articulou o município ao mercado internacional e fez que a commodity café passasse a se destacar na economia da região, que influenciou o próprio modo de vida, período conhecido como Belle Époque Caipira (Furtado, 2003; Ribeiro, 2006; Marcondes et al., 2015).
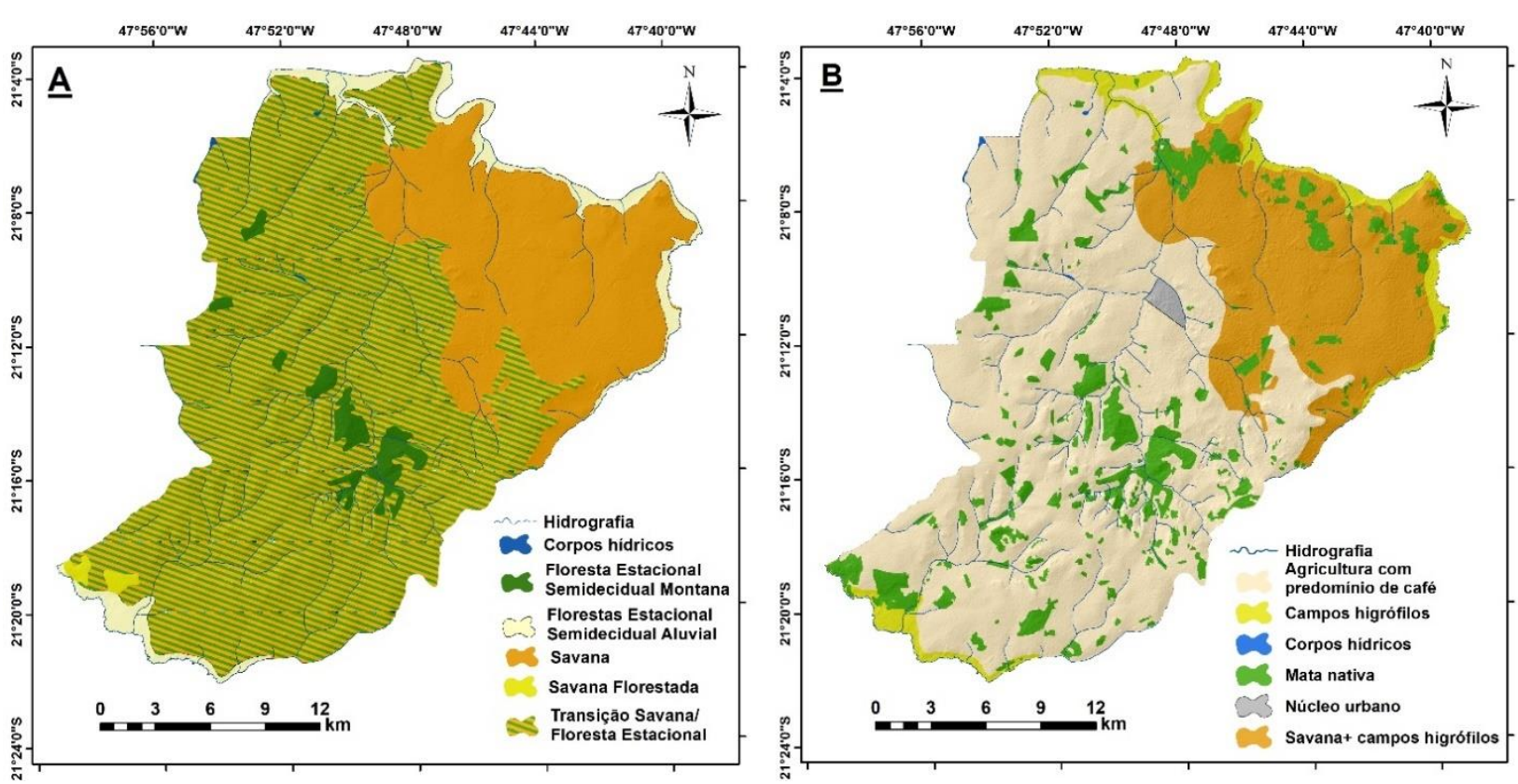

Figura 2 - (A) Vegetação pretérita de Ribeirão Preto (Adaptada de IBGE, 2012).

(B) reconstituição do uso e ocupação territorial do município por volta de 1900.

Na segunda metade do século XIX, o município passou por rápido crescimento demográfico, devido ao aumento do número de escravos e migrantes até 1886. Esta situação se intensificou com a chegada de estrangeiros para substituir a mão de obra cativa, com o fim da escravidão. Isto resultou em elevadas taxas de crescimento demográfico, em que a população mais que quintuplicou na última década do século XIX. Ribeirão Preto passou de 10.420 em 1886 para 59.195 habitantes em 1900, com população composta majoritariamente por imigrantes italianos. Além destes, migraram para o município, portugueses, espanhóis, austríacos e japoneses, como ilustra o crescimento populacional (Figura 3), que resultou na diversificação produtiva e crescimento do centro urbano e do comércio local (Emboaba, 1955; Marcondes et al., 2015). 
O café passou a ser a base econômica da região e levou o município a ser o maior produtor de café do Estado de São Paulo entre 1900 e 1920. Todavia, esta commodity sofreu continuas desvalorizações, devido à crise de superprodução em 1906, que levou o governo brasileiro a constituir o Convênio de Taubaté, que estabelecia preços mínimos para o café, entre outras garantias. Porém, a primeira guerra mundial aumentou a desvalorização desta cultura, o que somada à geada de 1918, levou a retração da produção de café, o que se acentuou depois de 1920 e ainda mais após a crise de 1929. Para piorar a situação, o café na região passou a sofrer a concorrência de produtores de outras regiões do país, dando início ao fim deste ciclo econômico, o que irá culminar com o plano de erradicação de cafeeiros em 1959 (Marcondes et al., 2015). Cabe destacar, que durante o Estado Novo (1937-1945), do Governo Vargas, que é marcado pela centralização do poder e pelo autoritarismo, as relações entre grupos de interesse foram drasticamente reestruturadas, fazendo com que os Barões do Café se sujeitassem a elite urbana composta por comerciantes e industriais que começavam a surgir e passam a ser nova fonte de poder, influindo nas políticas públicas, em detrimento da antiga República do Café com Leite, destituída por Getúlio Vargas, na terceira República Brasileira (Walker e Barbosa, 2000).

A matriz econômica do município, a partir de 1930, foi marcada pela redução da importância do café e pela diversificação produtiva, em que o setor terciário, de comércio e serviços, se torna a principal fonte de renda, que expandiu a área urbana e a atividade industrial. As políticas federais de substituição de importações criadas na Era Vargas (19301945), bem como o capital acumulado no ciclo do café forneceram as bases para o desenvolvimento comercial e agroindustrial da região. A primeira indústria foi uma subsidiária das Indústrias Reunidas Francisco Matarazzo, de beneficiamento de algodão. Estas características resultaram em um dinamismo econômico que marca Ribeirão Preto até os dias atuais (Walker e Barbosa, 2000; Marcondes et al., 2015). Tal condição repercutirá na dinâmica populacional do município, até então associada ao café e a partir de 1930 passa a ser condicionada pelo setor terciário e industrial, aumentando das taxas de crescimento populacional e redução da população rural (Figura 3) e, assim, a cidade passa a concentrar a maioria dos postos de trabalho.

Neste cenário, a área plantada por café foi substituída por outras lavouras como o algodão e a cana-de-açúcar já cultivadas na região, estabelecendo as bases de um novo ciclo agrícola e 
econômico regional. De toda forma, a produção de café afetará as políticas econômicas locais e nacionais até os meados do Século XX (Furtado, 2003). Como marcas desta época, temos a instalação dos telégrafos e da rede ferroviária articulada ao Porto de Santos e passou a reconfigurar a paisagem local, abrindo caminho para o novo ciclo econômico (Emboaba, 1955; Marcondes et al., 2015).

\subsection{Desenvolvimento tecnológico e agroindustrial: nova configuração de uso e cobertura} da terra

O desenvolvimento agroindustrial, a partir de 1930, é marcada pelo emprego de um conjunto de novas práticas agrícolas, com novas variedades de sementes, fertilizantes e pesticidas, mecanização com aumento na produtividade, que levou a abertura do mercado nacional às indústrias transnacionais, alterando a lógica do uso e ocupação do solo. A revolução verde, que começou na segunda metade do século XX nos países desenvolvidos foi introduzida nos ditos países subdesenvolvidos na década 1960. Esta revolução nas técnicas de produção agropecúarias e, neste contexto, associadas à finaceirização do setor, resultou em uma nova forma de regulação e novos instrumentos financeiros, que inseriram o município no mercado internacional via bolsas de valores, mercados futuros e holdings, implementadas pela revolução técnico-cientifica-informacional, o que deu origem ao predomínio do agronegócio sobre a agricultura familiar (Furtado, 2006). Então, cada vez mais, o campo nestas regiões de interesses comerciais internacionais, possui como característica o emprego de tecnologias sofisticadas e a mecanização de colheitas, que, somadas a fatores políticos, intensificam a migração do campo para a cidade, promovendo rápido e desordenado crescimento urbano (Figuras 3, 4 e 5 e Tabela 1). 


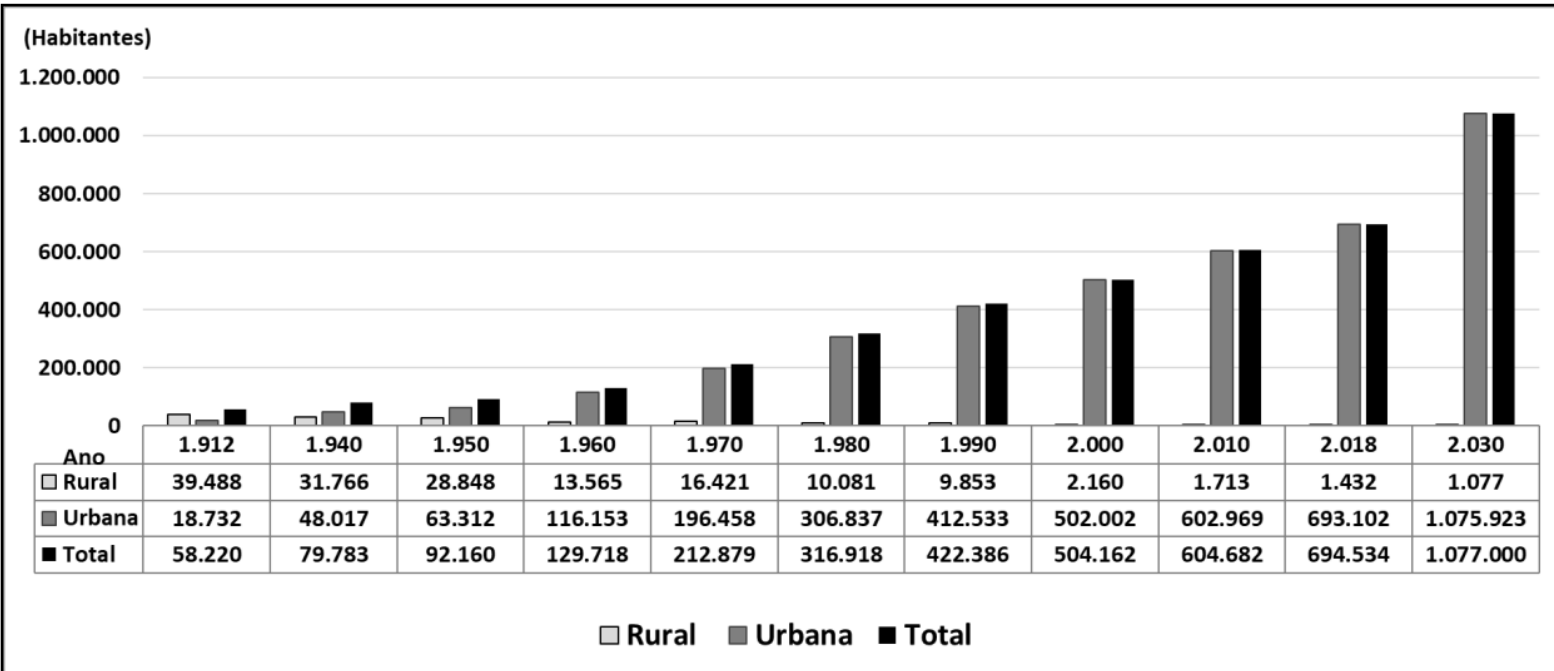

Figura 3 - População urbana, rural e total, período 1912-2018, e tendência para 2030.

Fonte: Bassanezi, 1998; PMRP, 2015; IBGE, 2019

Esse novo mercado exigiu a melhoria da qualificação de mão de obra rural frente às demandas de operação em redes de fornecimento globalizadas, levando a criação no município de várias instituições de ensino e centros de pesquisas públicos e privados, o que gerou, segundo relato de Ricardo Kotscho ao Jornal do Brasil, a alcunha de Califórnia Brasileira (PMRP, 2015). Cumpre destacar que em 1931 houve a promulgação do decreto de lei 19.717, que determina a mistura de álcool anidro à gasolina importada, levando em 1933 a criação do Instituto do Açúcar e do Álcool, responsável pela regulamentação e fomento do setor no Brasil (Brasil, 1931). 


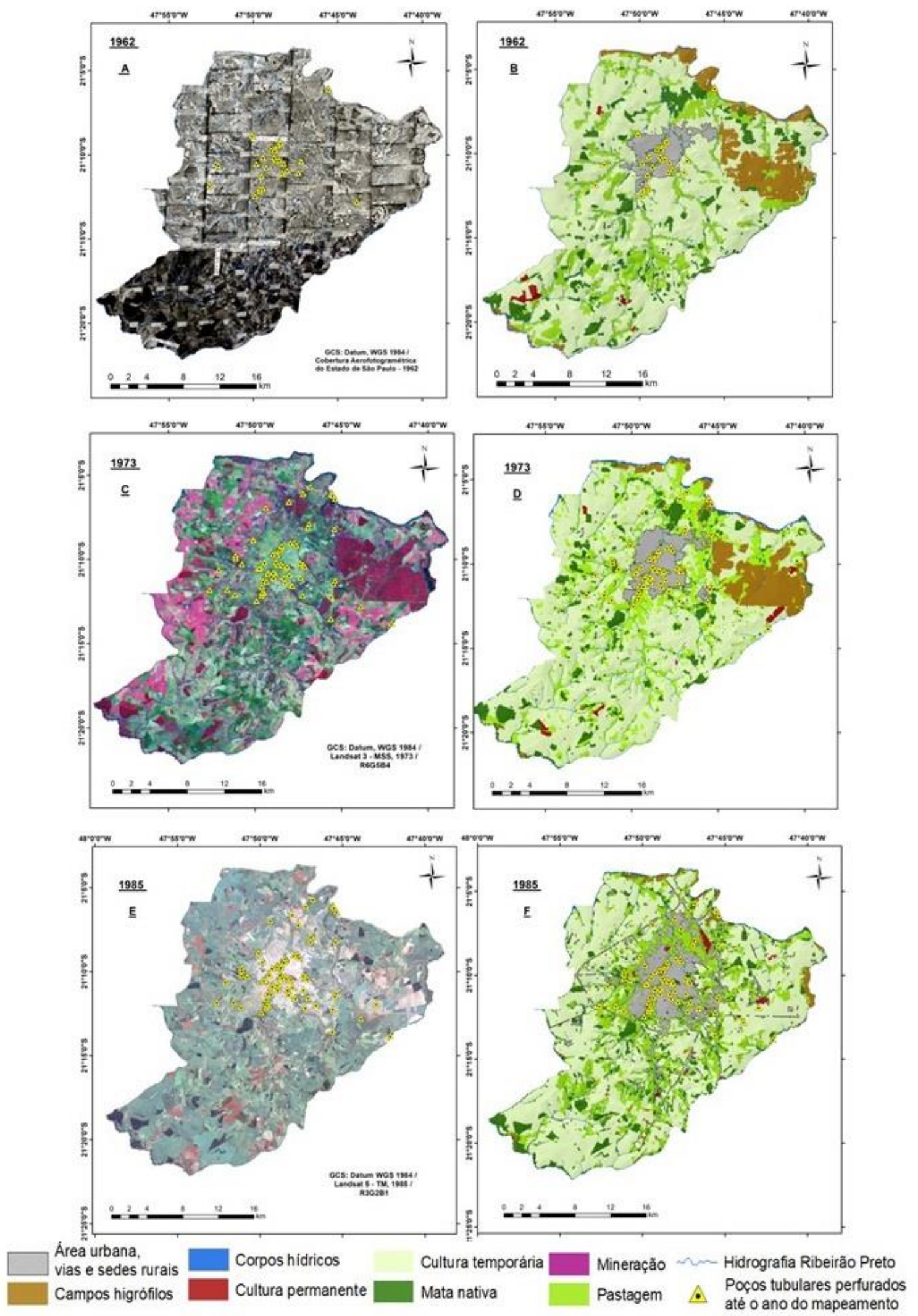

Figura 4 - Evolução do uso e cobertura do solo em Ribeirão Preto - 1962, 1973 e 1985. A, C, E = Imagens Brutas; B, D, F = Imagens classificadas. 1963 = fotografia aérea; 1973 = imagem Landsat 3; 1985 = imagem Landsat 5. 

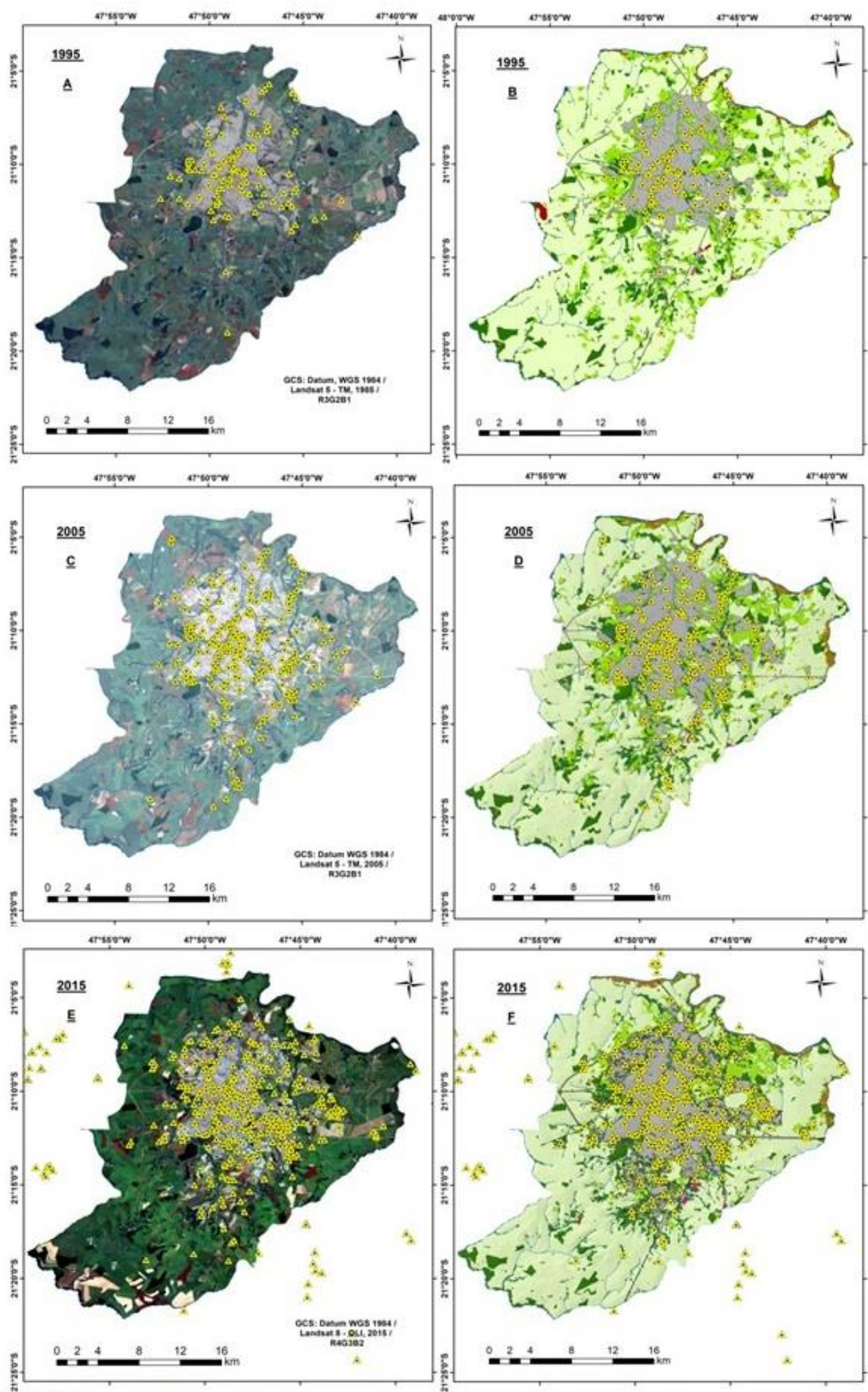

Area urbana

vias e sedes rurais

Corpos hidricos

Cultura temporária

Mineração

Hidrografia Ribeirão Preto

Campos higrófilos

Cultura permanente

Mata nativa

Pastagem

- Poços tubulares perfurados
até o ano do mapeamento

Figura 5 - Evolução do uso e cobertura do solo em Ribeirão Preto - 1995, 2005 e 2015. A, C, E = Imagens Brutas; B, D, F = Imagens classificadas. 1995 e 2005 = imagem Landsat 5; 2015 = imagem Landsat 8. 
A comparação entre os preços do açúcar e do álcool fazia com que o álcool fosse considerado residual. Apenas a partir de 1970, com os Planos Nacionais de Desenvolvimento - PND, dos governos militares, a atenção voltou ao setor de energia e ao álcool em resposta à crise mundial do petróleo. Assim, a criação do Proálcool buscou estabelecer um equilíbrio energético, protegendo o país das oscilações internacionais do preço do petróleo. Isto resultou no incentivo ao plantio da cana-de-açúcar, que se expandiu e se consolidou como eixo econômico estratégico em Ribeirão Preto e no país. Além disto, o desenvolvimento e seleção de organismos vegetais e animais, como a hibridização e/ou clonagem, permitiram o aumento da produtividade média por hectare. Isto aumentou o cultivo de culturas temporárias, (Tabela 1; Figuras 4 e 5), principalmente da cana-de-açúcar, que passa a ser a principal commodity local e torna Ribeirão Preto um dos principais polos sucroalcoleiros do mundo e que marca o ordenamento territorial na região (PMRP, 2015).

A área de cultura permanente, especificamente de plantio de café (Figura 2B), vem declinando no município desde 1930, resultado de fatores como a queda do preço do café e o aumento da demanda por combustíveis e açúcar, que somado a fatores fisiográficos locais, como solos e declividade, levou o município a substituir o café, base econômica do município desde sua fundação, pela cana-de-açúcar.

Tabela 1 - Evolução uso e cobertura do solo, Ribeirão Preto - 1963 a 2019.

\begin{tabular}{|c|c|c|c|c|c|c|c|c|c|c|c|c|c|c|}
\hline & 1962 & & 1973 & & 1985 & & 1995 & & 2005 & & 2015 & & 2019 & \\
\hline & Área (ha) & $\%$ & Área (ha) & $\%$ & Área (ha) & $\%$ & Área (ha) & $\%$ & Área (ha) & $\%$ & Área (ha) & $\%$ & Área (ha) & $\%$ \\
\hline Área urbana, vias & 2842,6 & 4,4 & 3765,7 & 5,8 & 8049,0 & 12,3 & 10816,6 & 16,6 & 13371,6 & 20,5 & 13563,4 & 20,8 & 16453,0 & 25,2 \\
\hline Campos higrófilos & 5389,4 & 8,3 & 5327,2 & 8,2 & 1117,6 & 1,7 & 718,3 & 1,1 & 855,7 & 1,3 & 1041,4 & 1,6 & 1417,5 & 2,2 \\
\hline Corpos hídricos & 178,2 & 0,3 & 546,8 & 0,8 & 308,3 & 0,5 & 250,3 & 0,4 & 278,6 & 0,4 & 465,8 & 0,7 & 280,4 & 0,4 \\
\hline Cultura Permanente & 1127,4 & 1,7 & 379,4 & 0,6 & 325,9 & 0,5 & 126,7 & 0,2 & 81,1 & 0,1 & 21,2 & 0,0 & 285,7 & 0,4 \\
\hline Cultura temporária & 39148,2 & 60,1 & 36702,6 & 56,3 & 35657,6 & 54,7 & 38158,4 & 58,5 & 35033,3 & 53,8 & 36959,2 & 56,7 & 31055,7 & 47,6 \\
\hline Mata nativa & 5998,3 & 9,2 & 4924,5 & 7,6 & 5645,8 & 8,7 & 4982,9 & 7,6 & 6943,1 & 10,7 & 6964,0 & 10,7 & 7287,7 & 11,2 \\
\hline Mineração & 3,3 & 0,0 & 20,6 & 0,0 & 37,1 & 0,1 & 40,3 & 0,1 & 65,7 & 0,1 & 67,1 & 0,1 & 69,5 & 0,1 \\
\hline Pastagem & 10489,3 & 16,1 & 13510,2 & 20,7 & 14035,5 & 21,5 & 10083,3 & 15,5 & 8547,8 & 13,1 & 6094,7 & 9,4 & 8327,4 & 12,8 \\
\hline TOTAL & 65176,8 & 100,0 & 65176,9 & 100,0 & 65176,8 & 100,0 & 65176,9 & 100,0 & 65176,8 & 100,0 & 65176,8 & 100,0 & 65176,8 & 100,0 \\
\hline Soma CHV+MN & 11387,7 & 17,5 & 5471,3 & 8,4 & 6763,4 & 10,4 & 5701,3 & 8,7 & 7798,9 & 12,0 & 8005,4 & 12,3 & 8705,2 & 13,4 \\
\hline
\end{tabular}

Legenda: Soma CHV + MN = Soma das áreas de campos higrófilos de várzea e mata nativa, que correspondem as áreas de vegetação nativa. ha = hectares.

O cultivo da cana-de-açúcar promoveu o desenvolvimento de um complexo agroindustrial em torno de sua produção, que a tornou mais vantajosa aos produtores locais e culminou 
no plano nacional de erradicação de cafezais, que praticamente eliminou esta cultura permanente no município. Assim, em 1963 a área de cultura permanente no município era de apenas 1.127 ha e continuou a ser reduzida até 2015, tendo um aumento em 2019, com 280 ha com silvicultura de eucalipto (Tabela 1 e Figuras 4 e 5).

\subsection{Estrutura fundiária, agronegócio e impactos produtivos sobre o uso do território}

A estrutura fundiária da época dos "Barões do Café" não sofreu grandes alterações, passando de empresas familiares para holdings e/ou sociedades anônimas em parceria com grupos internacionais, sem alterar a concentração de terras. Segundo São Paulo (2019), dos 48.406 ha de área agrícola em 2008, 61 estabelecimentos rurais ocupavam 33.946 ha, que correspondia a 70,1\% de área agrícola do município, enquanto 426 propriedades de até 200 ha ocupavam 14.459 ha, com 29,9\% da área. De qualquer forma, dos cerca de 700 mil habitantes, apenas 487 possuíam imóveis rurais em 2008, ou seja, apenas 0,068\% da população estava fixada no campo, que evidencia o intenso processo de desenvolvimento urbano e de êxodo rural (IBGE, 2019). Todavia, as políticas como o Programa Nacional de Agricultura Familiar - PRONAF, de 1996, e o Programa de Aquisição de Alimento do Governo Federal, que estimula a aquisição de alimentos da agricultura familiar são exemplos de políticas públicas que melhoram a condição dos pequenos agricultores, como os do Assentamento Mario Lago. Porém, contribuiu para redução dos campos higrófilos de várzea (Figuras 4 e 5).

Deve ser salientado ainda que o desenvolvimento agrícola do município, no ciclo do café, promoveu o desmatamento quase completo da vegetação nativa. Atualmente, há apenas fragmentos de Mata Atlântica e de Cerrado (Savana), que foram substituídos, primeiro pelo café (Figura 2A e 2B), e depois pelo o algodão e cana-de-açúcar (Brasil, 2012). A análise do uso e cobertura do solo do município (Figuras 4 e 5) aponta que vegetação nativa foi reduzida até 1995. Oliveira e Carvalho (1966) descrevem as matas, como: as raras e esparsas manchas remanescentes da vegetação original são os poucos atestados da exuberância das mesmas naquelas condições de solo, sobre terrenos mais úmidos e às margens dos rios, devido à maior dificuldade de ocupação humana. 
O aumento dos impactos ambientais e a quase completa devastação das matas nativas elevou os custos e causou a necessidade de preservar estes recursos, visto a intrínseca relação da produção agropecuária com a questão hídrica, os serviços ecossistêmicos e a estabilidade geológica e dos solos. Desde o Império já eram pensadas legislações voltadas para a questão da regulação da ocupação territorial, como a Lei de Terras, Lei no 601 de 1850, porém, foi a partir de 1930 que surgiram políticas voltadas à questão ambiental, como o Código Florestal de 1934, Decreto 23.793 de 1934, que regulamentava a obrigatoriedade de manter $25 \%$ da área dos imóveis com a cobertura de mata, a chamada quarta parte. Porém, devido às dificuldades de implementação, o Código Florestal de 1934 foi substituído pelo Código Florestal de 1965, Lei no 4.771, de 1965, explicitando o valor intrínseco das florestas e das vegetações nativas, além de definir as Áreas de Preservação Permanente (APP) e de Reserva Legal (RL), instituindo a necessidade de sua preservação e direcionando o seu uso (Servidoni et al., 2016).

A fragmentação florestal e o aumento do efeito de borda podem também estar associados à anistia dada, pelo Código Florestal de 2012, aos que desmataram RL até 22 de julho de 2008. Pois, a maioria dos fragmentos florestais ocorre em áreas próximas e nas várzeas (Figuras 4 e 5) e os agricultores são obrigados, de acordo com o Código Florestal de 2012, a recompor apenas as APP. Estas, devido às características naturais da região, são, em geral, matas ciliares, de canais retilíneos, de primeira e segunda ordem, o que resultam em fragmentos também retilíneos e com maiores efeitos de borda e, muitas vezes, não conectados. O município possui duas unidades de conservação a Área de Preservação Ambiental (APA) do Morro do São Bento, criada pela Lei Estadual n.o 6131 de 27 de 1988, com 1,9 ha, e a Estação Ecológica de Ribeirão Preto, Mata de Santa Tereza, com 154,2 ha (PMRP, 2015). 

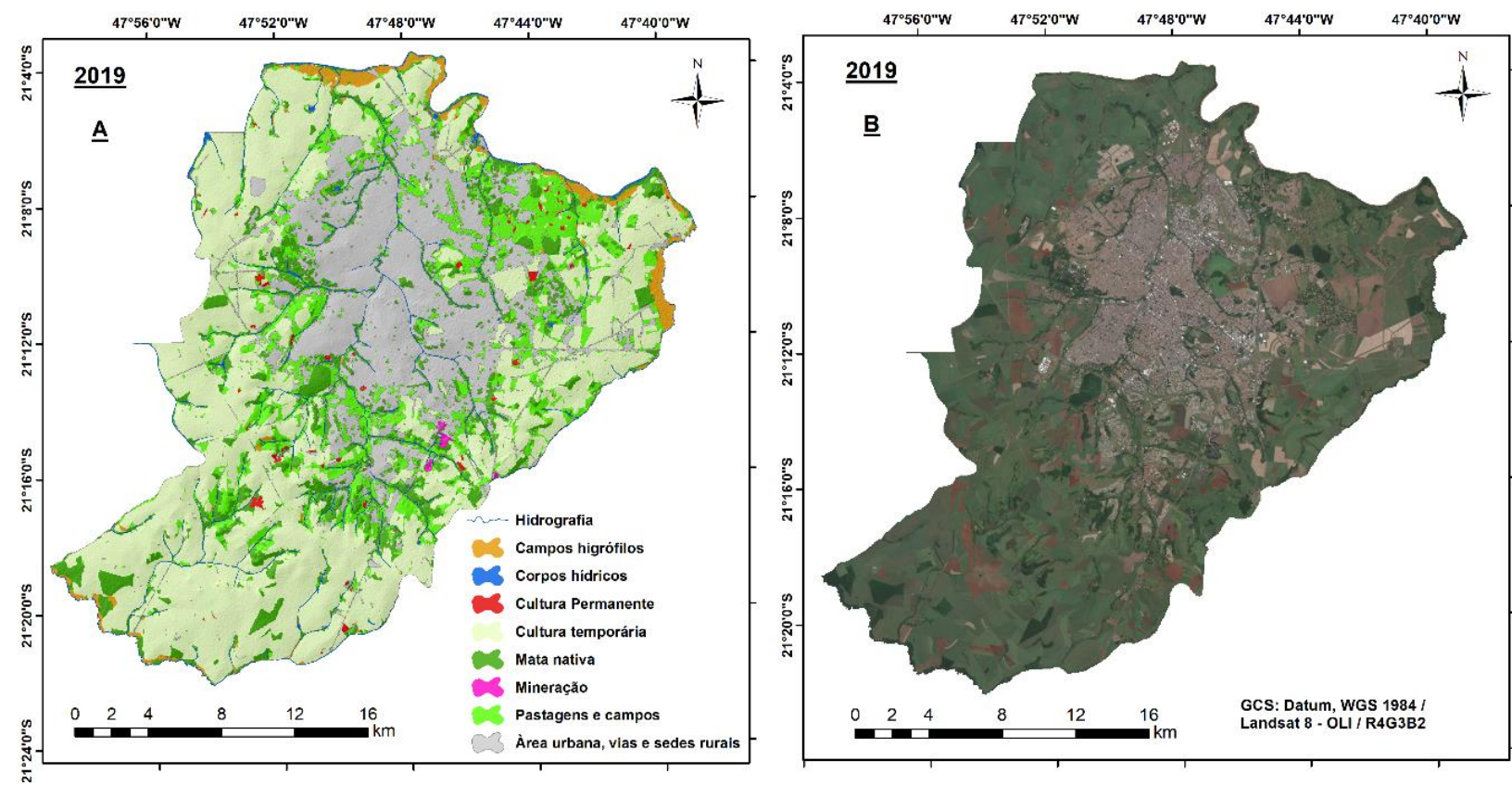

Figura 6 - A - Mapa do uso e cobertura do solo em Ribeirão Preto - 2019; B - Imagem Landsat 8 de abril de 2019.

As pastagens ocupavam em 1963, 16\% do município, valor próximo ao obtido para este uso por Oliveira e Carvalho (1966). As pastagens aumentaram progressivamente até 1985, atingindo 21\%, quando começaram a ser reduzidas até 9,4\% em 2015 e, então, voltaram a aumentar em 2019 (Tabela 1; Figuras 4, 5, 6 e 7). Este aumento até 1985 pode ser decorrência, do plano de erradicação de cafeeiros de 1959, que pode ter convertido cafezais em pastagens. Além disto, o crescimento da área urbana pode ter levado áreas do entorno urbano a serem transformadas em pastagens como em 2019, em decorrência da violência, como furtos e roubos das propriedades e, também, devido à especulação imobiliária.

\subsection{Produtividade agropecuária e expansão urbana}

A expansão e melhoria da infraestrutura, dos sistemas logísticos e das competências destinadas ao comércio e exportação de commodities, como Ceasa, Silos, Usinas Sucroalcoleiras, Centros de Pesquisa e Ensino, aumentaram a competividade do município e tornaram suas commodities mais atrativas. Assim, a expansão das culturas temporárias de 1930 até os dias atuais, tem relação principalmente, com o aumento da demanda, melhoria da infraestrutura e a qualificação da mão de obra, que tornaram a região competitiva internacionalmente. 
Apesar da redução da área plantada com culturas temporárias, estas tiveram ganho de produtividade resultando em aumento da produção (Pissinato e Viana, 2011), estas passaram de 60,7\% em 1963, para 47,7\% em 2019 (Tabela 1; Figuras 4, 5, 6 e 7). Esta redução na área plantada com cultivos temporários entre 1963 e 2019 (Figuras 4, 5 e 6), pode ser explicada pela expansão da área urbana sobre estas, além do aumento da demanda por combustíveis, na qual, à oscilação do preço do petróleo leva ao aumento ou à redução da demanda por álcool e consequentemente gera a expansão ou retração das áreas de plantio de cana-de-açúcar, que passam ser ocupadas com pastagens principalmente. Entre os anos de 1963 a 1985, foram expandidas também as áreas plantadas com cultivos de algodão e soja, sendo que o plantio de algodão foi sendo reduzido e praticamente não existe mais, já a cultura de soja tem se expandido e a partir do ano de 1995 passa a ocupar a segunda maior área agrícola no município (IBGE, 2015). Esta cultura têm apresentando uma tendência de aumento na área plantada, devido a alta demanda deste grão para a produção de ração para gado e para abastecimento de países como a China que é o maior comprador desta leguminosa. Isto tem levado, nos últimos anos, a susbtituição da cultura de cana-deaçúcar em algumas áreas por este grão. Além destas, é cultivado principalmente em pequenas glebas feijão, amendoim, milho, horticultura, compondo a classe de culturas temporárias do município.

O município conta ainda área de extração de basaltos, que se manteve estável entre 1963 e 2019, com valores de 0,01\% (Tabela 1 e Figuras 4, 5 e 6), devido ao uso na construção civil e na agricultura pela técnica de rochagem. Os corpos hídricos apresentaram variação principalmente em função da oscilação sazonal, do desmatamento, da irrigação e da construção de pequenos açudes, que também influenciam no nível d'água dos corpos hídricos.

A área urbana (Tabela 1) possuía em 1963, 4,4 ha, valor corroborado por Oliveira e Carvalho (1966), com 5,27\% em 1966 e atingiu 25,2\% do município em 2015 (Tabela 1). Tal aumento reflete o crescimento demográfico de quase 6 vezes, ou seja, de 129 mil habitantes em 1960 para cerca de 695 mil em 2018 e previsão de mais de 1 milhão em 2030 (IBGE, 2010; PMRP, 2015). Este crescimento foi mais acentuado nos últimos 40 anos, quando aumentou de cerca de 320 mil para cerca de 695 mil habitantes em 2018 (Figura 3) (IBGE, 2019). Tal crescimento demográfico reflete também a atração das populações do entorno rural e de 
mão de obra de outras regiões do país. Assim, é possível dividir o crescimento do município em duas fases principais.

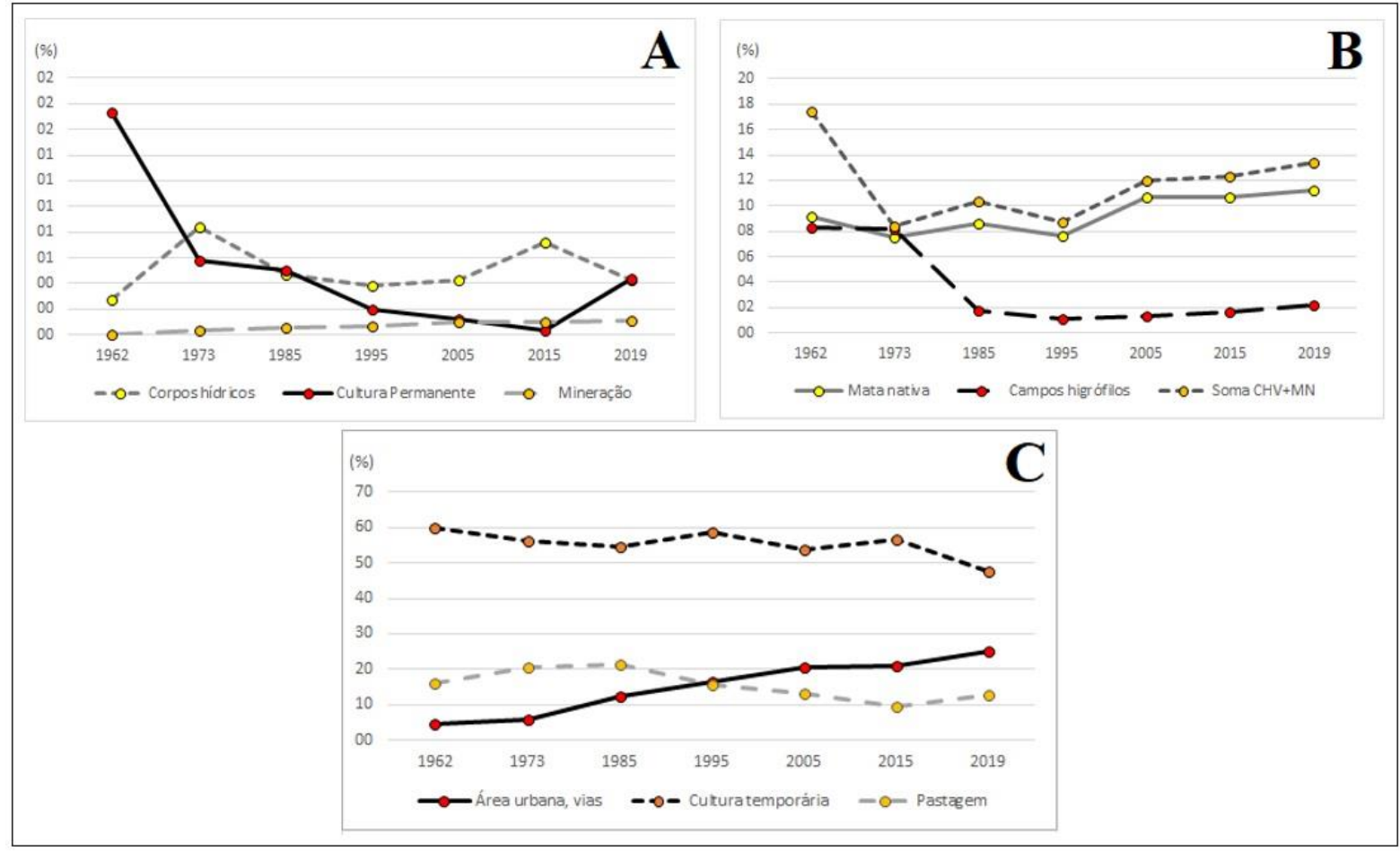

Figura 7 - Variação das classes de uso (\%) para os anos de 1962, 1973, 1985, 1995, 2005, 2015 e 2019. $\mathrm{CHV}=$ Campos Higrófilos de Várzea; $\mathrm{MN}=$ Mata Nativa

Na primeira, de 1860 até 1960, a dinâmica demográfica resultou principalmente do ciclo do café. O crescimento populacional foi de quase 15 vezes, de 5.552 em 1872, dominantemente de rurais, para 129 mil habitantes em 1962, com cerca de 90\% da população urbana, com uma área urbanizada de 2.843 ha ou $4,4 \%$ do município (Tabela 1 ). Em 1940, segundo PMRP (2015), o município já apresentava o predomínio da população urbana, devido à diversificação econômica e ao desenvolvimento dos setores agroindustrial e do comércio, situação potencializada pela revolução verde e a mecanização do campo, que resultou em elevadas taxas de crescimento demográfico de 1960 a 2015 (Tabela 1; Figuras 4 e 5).

Na segunda fase, a população cresceu de 129.718 em 1960 para 695 mil habitantes em 2019 (Figura 3), um crescimento de 575\%, enquanto a área urbana cresceu de 2.843 ha, ou $4,36 \%$, para $13.563,4$ ha ou $20,8 \%$ do munícipio (Tabela 1 ). Esta fase de desenvolvimento foi suportada pelos impactos da diversificação econômica, que resultou na instalação de agroindústrias, autarquias públicas, centros de pesquisa e ensino, expansão do comércio e 
serviços, com consequente atração e qualificação de mão de obra. A segunda fase foi mais democrática no processo de ocupação do território, permitindo que mais pessoas tivessem acesso aos bens e serviços da cidade, devido à maior expansão da área urbana. Isto reflete as políticas de facilitação de crédito, de distribuição de renda e de acesso à moradia, junto à melhoria da qualidade dos empregos, bem como do empreendedorismo da iniciativa privada.

Sobre o crescimento da área urbana podemos destacar duas situações distintas. $\mathrm{Na}$ primeira, entre 1962 e 1990, ocorreram altas taxas de expansão da área urbana, de 4\% para aproximadamente para $16 \%$ da área municipal, enquanto a população cresceu de 129.000 mil para cerca de 450.000. Na segunda, entre 1990 -2015, a área urbana cresceu a taxas menores, de 16 para 20\% do território, enquanto a população aumentou de 422.386 em 1990 para 674.405 em 2015. Nesta etapa, o processo foi marcado pela verticalização, devido ao aumento dos preços das propriedades e à especulação imobiliária. Ainda nesta fase, programas públicos, como o Minha Casa Minha Vida, que distribuía crédito imobiliário para pessoas de baixa e média renda, possibilitou o crescimento na construção civil e o aumento do número de moradias particulares.

\subsection{Legislação ambiental, recursos naturais e ordenamento territorial}

À medida que a população aumentava e a área urbana crescia foram necessários investimentos na preservação dos recursos hídricos. Assim, o primeiro sistema de abastecimento de água de Ribeirão Preto foi construído em 1903, por uma empresa privada, a Empresa de Água e Esgotos de Ribeirão Preto S/A. Em 1955 houve a quebra do contrato, pela Lei Municipal no 968 de 1960 e foi criado o Departamento de Água, Esgotos e Telefonia (DAET), que deu origem em 1969 ao Departamento de Água e Esgotos de Ribeirão Preto (DAERP), que além do fornecimento de água é encarregado pela coleta e tratamento dos esgotos e resíduos e pela limpeza pública. A água consumida e distribuída vem do SAG, com 103 poços tubulares para abastecimento público. Já os esgotos, são tratados na Estação de Tratamento de Esgotos Caiçara, de 2000, que trata 14\% do total coletado e a Estação de Tratamento de Esgotos Ribeirão Preto, que trata 84\% (PMRP, 2015). 
Desde o governo de Dom Pedro II havia a preocupação com a questão sanitária e com os recursos hídricos, como ilustra o Decreto no 1.929, de 1857 que aprova o contrato para o serviço da limpeza, destinação do esgoto e das águas pluviais da cidade do Rio de Janeiro. Com o destaque dado a questão ambiental no século XIX, em parte, pelas descobertas e trabalhos de John Snow, Robert Koch, Louis Pasteur entre outros, que demonstram a relação direta entre ambiente e saúde pública. Nesta conjuntura, a construção de redes de coleta de esgotos e de tratamento das águas de abastecimento passou a ser a resposta para as recorrentes epidemias de cólera, febre amarela, tifo e varíola que assolavam o país. Destarte, surgiu uma serie de políticas públicas voltadas à gestão sanitária, controle epidemiológico e preservação ambiental (Costa, 1994). Cabe ressaltar que os municípios eram abastecidos de água pelo modelo de distribuição coletiva e gratuita por meio de chafarizes, bicas e fontes que foi paulatinamente substituído, devido à necessidade de tratamento das águas. Assim, é ampliada a cobertura por rede de abastecimento e são desativados e demolidos os chafarizes públicos (Rolnik, 1998). Isto marca a transição da água como recurso gratuito, para a comercialização da água pelo serviço de abastecimento público (Murtha et al., 2015).

Devido ao crescimento urbano e populacional (Figuras 4, 5 e 7), a demanda por recursos hídricos aumentou exponencialmente, o que gerou a necessidade buscar novas fontes de água e resultou na perfuração do primeiro poço tubular no SAG em Ribeirão Preto em 1927, que aumentou para 83 poços tubulares no SAG em 1963, 95 em 1973; 150 em 1985; 309 em 1995, totalizando 419 em 2015, concentrados principalmente na área central da cidade (Figura 8A). O aumento da demanda pelos recursos hídricos determinou a necessidade de criação de mecanismos de gestão e de controle deste recurso, resultou na Deliberação CRH no 82, de 2008, que estabelece Áreas de Restrição e Controle Temporários a perfuração de novos poços tubulares na região central de Ribeirão Preto (Figura 8B).

Neste cenário, a ideia de sanear o ambiente, a teoria higienista, ganha destaque e questões que historicamente eram secundárias são deslocadas, no primeiro terço do século XX, para o centro do interesse nacional, pois interferem na organização do espaço urbano, na economia e na política (Murtha et al., 2015). Dessa forma, surgiram os primeiros sistemas de abastecimento de água no Brasil, como o de Ribeirão Preto em 1903, um dos pioneiros do país. Neste contexto, também surgirão políticas públicas voltadas à gestão dos recursos 
hídricos e naturais, como, Decreto n²4.643, de 1934, que estabeleceu o Código das Águas, ao qual seguiram outras políticas ambientais, como a constituição de 1934, a Lei n 2.312 de 1954, que estabelecia normas gerais sobre defesa e proteção da saúde, que culminou no Decreto $n^{\circ}$ 49.974, de 1961, conhecido como o Código Nacional de Saúde, a Lei n 5.318, de 26.09.1967, que cria o Conselho Nacional de Saneamento, que define formas de uso e manejo das águas e esgotos.

$\mathrm{Na}$ esfera federal, cabe destacar que a medida que a questão ambiental ficou mais complexa e necessária para a sustentabilidade ambiental e socioeconômica, surgiram normas, leis de ordenamento territorial e agências fiscalizadoras. Quanto a isso, deve ser destacada a Lei $\mathrm{n}^{\circ}$ 6.151, de 1974, que além de instituir o Plano Nacional de Desenvolvimento, tratava de temas como diversificação da matriz energética e política habitacional, que somado a criação da Política Nacional do Meio Ambiente pela Lei $n^{\circ} 6.938$, de 1981, com a criação do CONAMA - Conselho Nacional do Meio Ambiente, que comporá os órgãos deliberativos e consultivos do Sistema Nacional de Meio Ambiente - SISNAMA, regulado pelo Decreto $\mathrm{n}^{\circ}$. 88.351, de 1983.

Com o fim da ditadura militar brasileira (1964 - 1985), ocorreu a Promulgação da Constituição Federal de 1988, que abarcou um serie de temas relacionados à questão ambiental e ao uso do território e foram adotadas políticas voltadas à questão do direito a um ambiente saudável e equilibrado, com destaque, cada vez maior, para a questão do uso sustentável dos recursos naturais. Todavia, nem todas normas constitucionais saíram do papel e outras implementadas apenas parcialmente. Por exemplo, muitos municípios não possuem ainda nenhum tratamento de esgotos domésticos. Neste aspecto, a intensificação da fiscalização e autuação de crimes ambientais teve como resultado a criação de Agências de Fiscalização e Regulação como o Instituto Brasileiro de Meio Ambiente (IBAMA), criado pela Lei no 7.735 de 1989, ou o Conselho Nacional de Recursos Hídricos, criado pela Lei $n^{\circ}$ 9.433 de 1997 e a Agência Nacional de Águas - ANA, pela Lei n 10.257 de 2001. Muitas dessas agências tiveram suas ações fiscalizadoras neutralizadas pelo governo Jair Bolsonaro, a partir de 2019. Diante desse escopo, é possível notar uma significativa mudança no pensamento social e empresarial, que irá gradualmente, somado a outras iniciativas, promover uma mudança em relação a questões do uso e manejo do território (Figuras 7 e 8), que modificam comportamentos também em relação às formas de despejo de resíduos 
sólidos, de efluentes e emissões atmosféricas ou efluentes gasosos, que reflete a ampliação dos tratamentos de água e de esgotos em Ribeirão Preto e no país.

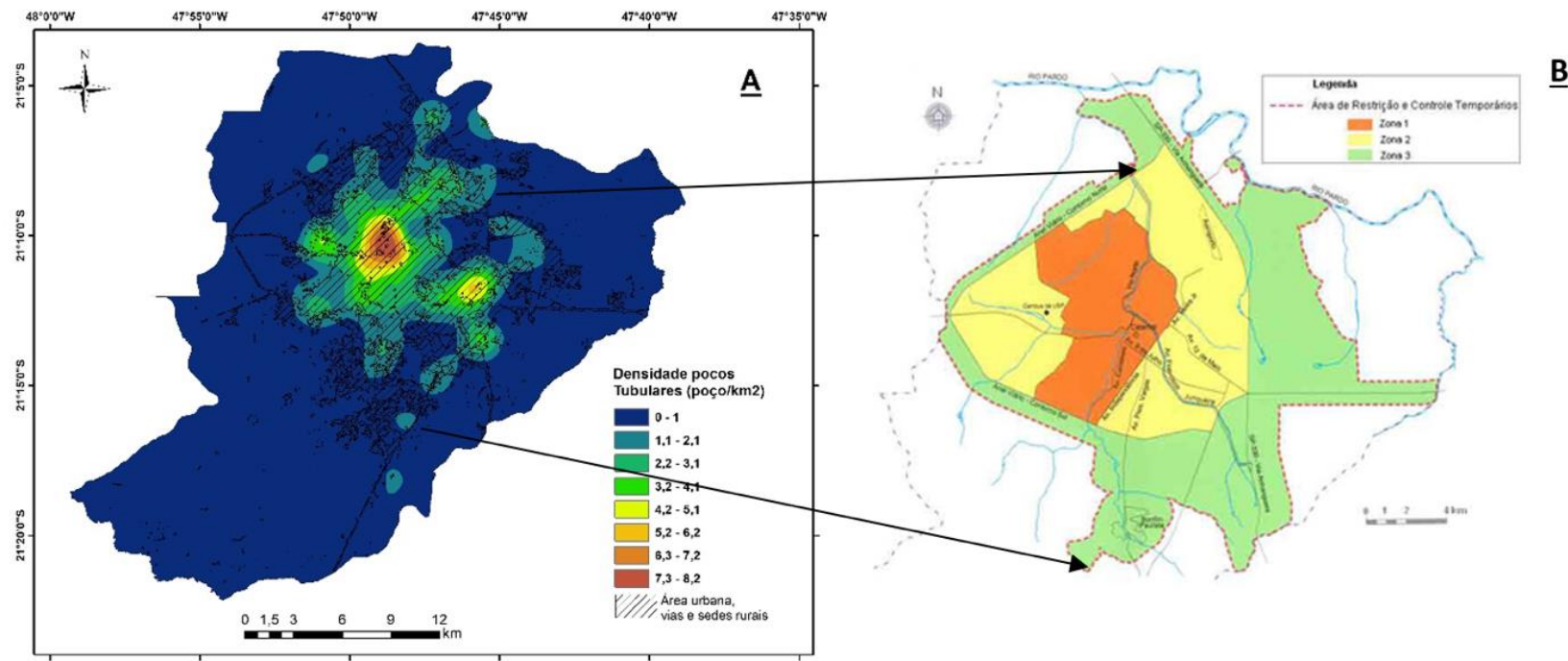

Figura 8 - A Quantidade de poços tubulares por $\mathrm{km}^{2}$, locados no Sistema Aquífero Guarani, cadastro DAERP/SIAGAS; B Mapa da zona de restrição e controle a perfuração de poços tubulares no Município de Ribeirão Preto.

Fonte: São Paulo (2008).

Na esfera estadual, houve a criação da FESB - Fomento Estadual de Saneamento Básico, pela lei $n^{\circ} 172$ de 1969, da CETESB Companhia Ambiental do Estado de São Paulo, Lei $n^{\circ} 118$ de 1973, o Decreto $n^{\circ} 73.030$ de 1973, que criou a Secretaria Especial do Meio Ambiente, no

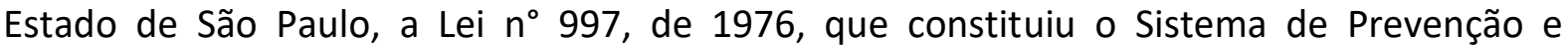
Controle da Poluição do Meio Ambiente, que proíbe o lançamento ou liberação de poluentes no ar, agua e solos e o Decreto $n^{\circ} 79.367$, de 1977 , que dispôs sobre normas e padrões de potabilidade da água, a Lei Estadual $n^{0} 6.134$ de 1988, que dispõe sobre a preservação dos recursos hídricos subterrâneos, assim como a Lei Estadual no 7.663 de 1991, que instituiu a Política Estadual de Recursos Hídricos e cria o Sistema Integrado de Gerenciamento de Recursos Hídricos - SIGRH, o Plano Estadual de Recursos Hídricos - PERH e o Fundo Estadual de Recursos Hídricos - FEHIDRO (Nazo e Mukai, 2001) e o Decreto-Lei nº 32.955 de 1991, que trata sobre as águas subterrâneas e estabelece critérios de outorga e de uso das mesmas. Esta dinâmica tem promovido à expansão gradual do saneamento básico, considerando que até 1990, em Ribeirão Preto, apenas $2 \%$ dos efluentes eram tratados e a maioria despejada in natura no Rio Pardo e atinge em 2019 o tratamento de 
98\% dos esgotos da área urbana, além da disposição do lixo em aterros sanitários em substituição aos lixões e aterros controlados no ano de 2006 (PMRP, 2017).

O aumento da pressão pública e a necessidade de desenvolvimento de cidades, com vistas a atender às demandas de melhoria da qualidade de vida dos seus moradores, é promulgado Estatuto das Cidades pela Lei $n^{\circ} 10.258$ de 2001, que institui o planejamento participativo e a função social da propriedade, possibilitando o uso dos espaços públicos e a escolha da destinação dos recursos públicos para projetos escolhidos de forma descentralizada pela população. Especificamente, no Município de Ribeirão Preto, é importante destacar que o Plano Diretor Municipal, pela Lei Municipal n 501 de 1995, foi um dos primeiros do país, o que acaba por alterar as características da área urbana em algumas regiões, levando, mesmo que de modo incipiente, a ampliação de áreas verdes, praças e parques, assim como da infraestrutura básica de escolas e centros de saúde e conjuntos habitacionais.

Este conjunto de leis tem promovido novas diretrizes e repercutido sobre o uso, a ocupação e o manejo do território, regulamentando as atividades potencialmente poluidoras e que degradam o ambiente e melhorando a questão da disposição e tratamento dos resíduos sólidos, efluentes e emissões atmosféricas, do uso da água, das matas e do solo no país. No Município de Ribeirão Preto elas resultaram em profundas alterações da dinâmica de uso e ocupação territorial e, sem dúvida, são o principal fator de recuperação gradual das áreas de matas nativas a partir de 1980 (Figuras 4, 5 e 6) e são de suma importância devido à dependência dos municípios dos recursos naturais. Tais recursos, em Ribeirão Preto, foram, por muitas vezes, utilizados de maneira insustentável, como a instalação de um lixão sobre área de recarga do SAG, o quase completo desmatamento das matas nativas (Figuras 2 e 7), com aumento das taxas de erosão e da poluição dos rios. Mas, ainda resta disposição de lixo em terrenos baldios e despejo clandestino de efluentes nos rios.

As alterações do uso e ocupação dos solos na área, apesar dos investimentos, apontam para intensificação da degradação dos recursos naturais solo, água e vegetação. Em geral, as culturas temporárias apresentam tendência de taxas a erosão hídrica maiores do que a vegetação nativa e pastagens. Isto resulta de práticas como aragem, gradagem, escarificação, plantio mecanizado, uso excessivo de agroquímicos, pastagens em lotação contínua e sem adubação, ausência de manejos conservacionistas e irrigação intensiva. Tais processos, em muitos casos, são insustentáveis e danosos também aos recursos hídricos, 
com o transporte de sedimentos e o assoreamento dos corpos d'água, que podem carrear junto com os sedimentos também contaminantes, como pesticidas, patógenos e metais pesados (Carvalho, 2008), que afetam a qualidade das águas e a cadeia trófica. No caso, por ser uma área de afloramento do SAG poderá comprometer toda a população, além da biodiversidade e os serviços ecossistêmicos e ambientais prestados pela natureza. Além disso, o uso frequente de fertilizantes pode contribuir para a eutrofização de ecossistemas aquáticos, devido ao seu carreamento pelas águas de escoamento superficial, que é potencializada ainda mais pela ausência das APP (Brady e Weil, 2013; Servidoni et al., 2016). $\mathrm{Na}$ área é nítida a ausência de áreas de APP e RL, que têm a função ambiental de preservação dos recursos hídricos, da paisagem, da estabilidade geológica, da biodiversidade, do fluxo gênico da fauna e flora e de assegurar o bem-estar das populações (Blanco e Lal, 2008). Segundo Blanco e Lal (2008), áreas com maior quantidade de matas nativas sofrem menos ação de pragas e de vetores de doenças como o mosquito do gênero "aedes", e no médio e longo prazo ganham em produtividade agrícola, resultado do aumento da polinização pelos insetos, atenuação do escoamento superficial e concomitante redução da erosão, aumento do teor de matéria orgânica; de umidade e melhoria na estrutura do solo, etc. Todavia, na região, estes serviços ecossistêmicos prestados pela fauna e flora são afetados pela redução e degradação das áreas de vegetação nativa e o aumento dos efeitos de borda (Figuras 4 e 5).

Diante disso, a melhoria no manejo e a preservação e recuperação das APP e RL podem ajudar, no longo prazo, na garantia do equilíbrio hidrossedimentológico da área, com a preservação dos solos, dos polinizadores, dos recursos hídricos, pois as alterações das taxas de erosão podem contaminar o SAG, devido às infiltrações contaminantes.

\subsection{Considerações futuras sobre uso, ocupação e manejo da terra}

O município cresceu numa região de planície de fundo de vale e agora se encontra limitado por áreas de relevos mais íngremes ao sul e pela área de afloramento do SAG ao norte. De tal modo, o ordenamento da expansão territorial deve buscar o estabelecimento de eixos e vetores para expansão da área. Deve, assim, evitar ocupação de áreas de afloramento do SAG ao norte e as áreas íngremes ao sul. A região oeste e sul se apresentam como as áreas 
adequadas para a expansão urbana, por serem mais planas e não estarem sobre área de recarga do SAG. Além disto, devem ser elaborados planos de abastecimento, a regulamentação da coleta de água superficial na Bacia do Rio Pardo e uma avaliação precisa dos recursos hidrogeológicos, para evitar que a superexploração e a poluição não prejudiquem o abastecimento de água.

A legislação do ordenamento territorial é e foi muito desrespeitada, como resultado dos lobbies de alguns setores sobre os políticos, o que resultam em atrasos para o desenvolvimento e aplicação da legislação, assim como em seguidas emendas constitucionais ou completa alteração destas, levando ao não cumprimento das leis e a um sentimento de impunidade, que se reflete no surgimento de bairros e ocupações irregulares e na demora para instalação de obras de saneamento básico, ocupação das APP e RL, superexploração e poluição das águas, etc. Assim, a questão ambiental deve ser tratada como questão estratégica de desenvolvimento, com o fortalecimento de seus órgãos e mecanismos de fiscalização em todas esferas de poder e ensinada como uma questão imperativa (Calderon e Cuesta, 2017).

O atual governo brasileiro, todavia, tem promovido a alteração e enfraquecimento das políticas públicas voltadas ao ordenamento territorial e à preservação ambiental, que geram incertezas sobre o processo de regulamentação da dinâmica de uso, ocupação e manejo no futuro próximo. Porém, já sentimos o efeito destas políticas no que tange à Floresta Amazônica, que sofreu um aumento de 35\% no seu desmatamento no ano de 2019 e de 9,5\% em janeiro de 2020 (Terra Brasilis, 2020), o que pode no longo prazo comprometer as chuvas na região sudeste do país, afetando o agronegócio. Adicionalmente, há o aumento da pobreza e o processo de desindustrialização que o país sofre, que pode resultar em graves problemas no futuro, além da ampliação do uso de agroquímicos na agropecuária sem os devidos critérios técnicos, que pode ampliar a contaminação dos ecossistemas.

De tal modo, práticas que preservem o ambiente como a manutenção das APP e RL, assim como o uso do território de forma ordenada e planejada devem ser prioridade. Para tanto deveriam ser criadas ou atreladas linhas de crédito às propriedades que utilizem manejos conservacionistas e/ou preservem as APP e RL, assim como abatimento de impostos. Igualmente, poderiam ser exigidos e criados novos selos de rastreabilidade ecológica que agregam valor aos produtos. De toda forma, é necessário, cada vez mais, a qualificação da 
mão de obra, programas de conscientização e fiscalização dos produtores rurais e da sociedade em geral, que devem ser mais frequentes e efetivos. É necessário também um amplo investimento em ciência e tecnologia para barrar a desindustrialização e a redução dos postos de trabalho.

\section{Conclusões}

A urbanização intensificada a partir da década de 1960 com a migração populacional da zona rural para o centro urbano é destacada em Ribeirão Preto, polo centralizador desta migração na região noroeste do Estado de São Paulo. As propriedades ainda herdam as características históricas de ocupação, em que grandes quantidades de terras pertencem a poucos grupos econômicos favorecidos pelo poder público.

$\mathrm{Na}$ área urbana, o adensamento implica em maior demanda de água de abastecimento, que é proporcionado pelo Aquífero Guarani, que já possui uma delimitação ampliada de restrição e controle do uso na mancha urbana.

A baixa porcentagem de áreas vegetadas por Mata Atlântica e Cerrado (Savana), e das matas ciliares é decorrente de práticas agrícolas não sustentáveis desde o século retrasado. Apesar de um ligeiro aumento destas vegetações, atualmente a região ainda está sujeita a agravamentos da erosão, do assoreamento de cursos de água e da poluição dos recursos hídricos superficiais por eutrofização e agroquímicos.

Atualmente, está ocorrendo o enfraquecimento dos órgãos fiscalizadores e uma série de alterações da legislação pública, visando, novamente uma flexibilização nas relações sociais, de trabalho e do uso e ocupação do espaço, que podem resultar em efeitos deletérios sobre os ecossistemas e sobre a qualidade de vida na região e da população brasileira em geral.

\section{Agradecimentos}

O presente trabalho foi realizado com apoio da Coordenação de Aperfeiçoamento de Pessoal de Nível Superior - Brasil (CAPES) - Código de Financiamento 001.

\section{Referências Bibliográficas}


ALVARES, C. A.; A.; STAPE J. L.; SENTELHAS P. C.; GONÇALVES, J. L. M.; SPAROVEK, G. (2014). Köppen's climate classification map for Brazil. Meteorologische Zeitschrift, Stuttgart, v. 22, n. 6, p. 711-728. DOI: 10.1127/09412948/2013/0507

ARAÚJO, A. L. (2017). Reparations for Slavery and the Slave Trade: A Transnational and Comparative History. 1. ed. London: Bloomsbury Academic. 288p.

BARROS, R. (2005). História da História da Fundação de Ribeirão Preto. 1. ed. Ribeirão Preto: Editora Legis Summa Ltda.

BASSANEZI, M. S. C. B. (2020). São Paulo do passado: dados demográficos: Período1836 - 1920. Disponível em: https://www.nepo.unicamp.br/publicacoes/censos.php. Acesso em: 10 de fevereiro de 2020.

BLANCO, H., LAL, R. (2008). Principles of soil conservation and management. 1. ed. Heidelberg: Springer. 641p.

BRADY, N. C.; WEIL, R. R. (2013). Elementos da natureza e propriedades dos solos. 3. ed. Porto Alegre: Bookman. 716p.

BRASIL. (1931). Assembleia legislativa do Brasil. Decreto no 19.717, de 20 de fevereiro de 1931. Disponível em: http://www2.camara.leg.br/legin/fed/decret/1930-1939/decreto-19717-20-fevereiro-1931518991 publicacaooriginal-1-pe.html Acesso em: 6 de dezembro de 2019.

BRASIL. (2012). Decreto no 7.830, de 17 de outubro de 2012. Dispõe sobre o Sistema de Cadastro Ambiental Rural. Diário Oficial da União, Brasília, DF. 2012. Disponível em: <http://www.planalto.gov.br/ccivil_03/_Ato20112014/2012/Decreto/D7830.htm>. Acesso: 25 de abril de 2016.

CALDERÓN, B.; CUESTA J. L. G. (2017). Legislación urbanística y planeamiento urbano em España, 1998-2015. Del despilfarro a la sostenibilidad. Scripta Nova, Barcelona, v. 21, n. $570 . \quad$ p. $560 \quad-57$. DOI: 10.1344/sn2017.21.19429

CARVALHO, N. O. (2008). Hidrossedimentologia Prática. 2. ed. Rio de Janeiro: Interciência. 602p.

CGGESP - COMISSÃO GEOGRÁFICA E GEOLÓGICA DO ESTADO DE SÃO PAULO. (1910). Mapa de uso e cobertura do Estado De São Paulo. $1910 . \quad$ Disponível em: https://www.infraestruturameioambiente.sp.gov.br/institutogeologico/laboratorioegeotecnologia/geoprocessamento/. Acesso em: 14 de dezembro de 2019.

COSTA, A. M. (1994). Análise histórica do saneamento no brasil. Dissertação (Mestrado em Saúde Pública) Escola Nacional de Saúde Pública, Fundação Oswaldo Cruz, Rio de Janeiro. 164p.

EMBOABA, O. (1955). História da Fundação de Ribeirão Preto. Revista de História, São Paulo, v. 10, n. 21-22, p. $339-438$.

EMBRAPA (2018). Visão 2030: o futuro da agricultura brasileira. 1. ed. Brasília: Embrapa. 213p.

FELDE, G. W.; ANDERSON, G. P.; COOLEY, T.; MATTHEW, M. W.; ADLER-GOLDEN, S.M.; BERK, A.; LEE, J. (2003). Analysis of Hyperion Data with the FLAASH Atmospheric Correction Algorithm, IEEE, Transactions on Geoscience and Remote Sensing, New York, p. 90-92. DOI: 10.1109/IGARSS.2003.1293688

FREDERICO, N. T. (1984). Alimentação e avaliação do estado nutricional de trabalhadores migrantes e safristas na região de ribeirão Preto, SP (Brasil). Revista Saúde Pública, São Paulo, v. 18, n. 5, p. 375-81, 1984. DOI: 10.1590/S0034-89101984000500007

FURTADO, C. (2003). Formação econômica do Brasil. 32. ed. São Paulo: Cia. Editora Nacional. 2003. 352p.

HUANG, C.; DAVIS, L. S.; TOWNSHEND, J. R. G. (2002). An assessment of support vector machines for land cover classification. International Journal of Remote Sensing. Nottingham, v. 23, n.4, p.725-749. DOI: 10.1080/01431160110040323

IBGE - INSTITUTO BRASILEIRO DE GEOGRAFIA E ESTATíSTICA. (2006). Censo agropecuário 2006: Tabela 840. Disponível em: http://www.sidra.ibge.gov.br/. Acesso em: 25 de fevereiro de 2020.

IBGE - INSTITUTO BRASILEIRO DE GEOGRAFIA E ESTATÍSTICA, (2010). Censo populacional, dados demográficos e economia. Disponível em: https://www.ibge.gov.br. Acesso em: 25 de fevereiro de 2020. 
IBGE - INSTITUTO BRASILEIRO DE GEOGRAFIA E ESTATÍSTICA, (2015). Cidades - Ribeirão Preto. Disponível em: <http://www.cidades.ibge.gov.br/xtras/perfil.php?lang=\&codmun=310160\&search=| | inogr\%E1ficos:informa\%E7\%F5es-completas>. Acesso em: 08 de Julho de 2019.

IBGE. INSTITUTO BRASILEIRO DE GEOGRAFIA E ESTATÍSTICA, (2019). Estimativas da da área dos imóveis rurais no Brasil e unidades da federação. Disponível em: https://sidra.ibge.gov.br/tabela/2727. Acesso: 04 de novembro de 2017.

IBGE - INSTITUTO BRASILEIRO DE GEOGRAFIA E ESTATÍSTICA, (2012). Mapa da vegetação pretérita do Brasil. Disponível em: https://www.ibge.gov.br/geociencias/informacoes-ambientais/vegetacao.html Acesso em: 08 Julho de 2019.

IBGE - INSTITUTO BRASILEIRO DE GEOGRAFIA E ESTATÍstICA, (2013). Malha Municipal Digital do Brasil. Disponível em: https://www.ibge.gov.br/geociencias/organizacao-do-territorio/malhas-territoriais/15774malhas.html?edicao=27427\&t=acesso-ao-produto Acesso em: 08 de juJulho de 2019.

MARCONDES, R. L.; REGISTRO T. C.; GUAZZELI, A. M. C. (2015). Ribeirão Preto: a cidade como fonte de pesquisa. 1. vol. Ribeirão Preto: Universidade de São Paulo.

MARTÍNEZ, E. (2014). Configuracion urbana, hábitat y apropiación del espacio. Scripta Nova, Barcelona, v. 33, n. 493, p. $01-19$.

MURTHA, N. A.; CASTRO, J. E.; HELLER, L. (2015). Uma perspectiva histórica das primeiras políticas públicas de saneamento e de recursos hídricos no brasil. Ambiente \& Sociedade, Uberlândia, v. 18, n. 3, p. 193-210, 2015. DOI: 10.1590/1809-4422ASOC1047V1832015

NAZO, G. N.; MUKA, T. (2001). Direito ambiental no Brasil: evolução histórica e a relevância do direito internacional do meio ambiente. Revista Direito Administrativo, Rio de Janeiro, v. 223, n. 1, p. 117-145. DOI: 10.12660/rda.v223.2001.48313

OLIVEIRA, J. B.; CARVALHO, A. (1996). Uso do solo no município de Ribeirão Preto, Estado de São Paulo. Boletim paulista de Geografia, São Paulo, v. 43, n. 1, p. 5-58.

PISSINATO, B.; VIANA, C. E. F. (2011). A cultura da cana de açúcar no estado de São Paulo entre 1950 e 2010 : evolução histórica da área e produtividade. 2011. Dissertação (Mestrado em Economia Aplicada) Escola Superior de Agricultura Luiz Queiroz, Universidade de São Paulo, Piracicaba. 161p.

PMRP - PREFEITURA MUNICIPAL DE RIBEIRÃO PRETO, (2015). Plano municipal de saneamento básico e plano municipal de gestão integrada de resíduos sólidos de Ribeirão Preto. 1. ed. Secretaria de Administração. 107p.

PONZONI, F. J.; SHIMABUKO, Y. E.; KUPLICK, T. M. (2012). Sensoriamento Remoto da vegetação. 2. ed. São Paulo: Oficina de Textos. 176p.

RIBEIRO, D. (2006). O povo brasileiro. 2. ed. São Paulo: Companhia das Letras. 368p.

ROLNIK, R. (1998). Para além da Lei: legislação urbanística e cidadania (São Paulo 1886- 1936). In: Edésio Fernandes. Direito Urbanístico. Belo Horizonte: Editora Livraria Del Rey. p. 169 - 202.

SÃO PAULO - COORDENADORIA DE ASSISTÊNCIA TÉCNICA INTEGRAL . (2019). Levantamento censitário das unidades de Produção agropecuária do estado de São Paulo: Tabelas 478.1 e 481.1, estáticas agrícolas Município de Ribeirão Preto. Dsiponível em http://www.cati.sp.gov.br/projetolupa/. Acesso em: 12 de fevereiro de 2020.

SÃO PAULO - SECRETARIA DE MEIO AMBIENTE (2008). Deliberação no 065/06 e Deliberação CBH-Pardo $n$ o 003/08. Comitê de Bacias do Rio Parado. 2008. Disponível em: http://www.sigrh.sp.gov.br/public/uploads/events//CRH/CTAS/4650/del-cbh-pardo-2292016.pdf. Acesso em: 20 de janeiro de 2020.

SERVIDONI, L. E.; AYER, J. E. B.; SILVA, M. L. N.; SPALEVIC, V.; MINCATO, R. L. (2016). Land use capacity and environment services. Revista Brasileira de Geografia Física, Recife, v. 9, n. 6, p. 1712-1724. DOI: 10.26848/rbgf.v9.6.p1712-1724

SINELLI, O. (1973). Mapa geológico do nordeste do Estado de São Paulo. Escala 1:50.000 - Folhas de Serrana, Ribeirão Preto, Cravinhos e Bonfim Paulista. Convênio CNEC/FFCL. Ribeirão Preto: Universidade de São Paulo, 
1973. Disponível em: https://www.ribeiraopreto.sp.gov.br/files/splan/planod/solo-produto-4.pdf . Acesso em: 24 de janeiro 2020.

TERRA BRASILIS. (2020) Prodes: taxas de desmatamento. Disponível em: <http://terrabrasilis.dpi.inpe.br/app/dashboard/deforestation/biomes/legal_amazon/rates>. Accesso em: 10 de fevereiro de. 2020.

USGS - UNITED STATES GEOLOGICAL SURVEY. (2016). Frequently asked questions about the Landsat missions. Disponível em <http://landsat.usgs.gov/band_designations_landsat_satellites.php >. Acesso em: 3 agosto de 2016.

WALKER, T. W; BARBOSA, A. S. (2000). Dos coronéis à metrópole: fios e tramas da sociedade e da política em Ribeirão Preto no Século XX. Ribeirão Preto: Palavra Mágica. 222p. 